\section{National identities blur}

\section{Tokyo}

THE United States is still forging ahead of Japan in the development of biotechnology, according two recent US reports. But Japan is the United States' leading competitor, particulary in the application of biotechnology to the development of new drugs. Such comparisons of the two countries, however, are beginning to lose meaning as more and more US and foreign companies set up research and development operations in Japan.

A survey by the US Federal Drug Administration (FDA) of Japanese companies that use biotechnology to produce pharmaceutical products found 9 products approved for marketing and 143 in various stages of research and development. The most intensive efforts are concentrated on agents that prevent or break up clots; vaccines to prevent various viral infections; interleukins to stimulate patients' immune response; colony stimulating factors to enhance the numbers of various cells present in the blood at lower than normal levels; and interferons for treatment of cancers or viral infection.

Cancer is a major focus of Japanese research with well over half of the products directed at cancers or related conditions. But, although Japanese production of new drugs using biotechnology is "robust", the United States holds roughly a two-to-one lead in both the number of companies involved and number of products, according to the FDA.

A survey by the US Pharmaceutical Manufacturers Association of biotechnology patents issued in the United States between 1986 and 1988 reaches a similar conclusion. Of the 237 patents issued for genetic-engineering techniques, US companies account for 195, Japanese companies for 22 and Western European 13.

Mitsuru Miyata, editor-in-chief of the Japanese newsletter Nikkei-Biotechnology, adds the tremendous effort that Japanese companies are now expending on the development of monoclonal antibodies to the FDA list. But he questions the value of comparative studies, given the growing multinational character of industrial research and development.

In the past, US companies licensed techniques in biotechnology to Japanese companies. But the recent trend is for US and foreign companies to carry out their own clinical trials and research and development in Japan. A good example is growth hormones where early products were developed by Japanese companies with licences from foreign companies; Eli Lilly and Serono Laboratories are now conducting their own clinical trials in Japan, according to Miyata.

The phenomenon is not confined to biotechnology. The huge chemical comNAZI VICTIMS

panies DuPont and ICI recently set up research institutes in Japan, as has the West German drug manufacturer Hoechst and the Swiss giant Ciba-Geigy.

IBM has long had basic research facilities in Japan, and LSI Logic, a US semiconductor company, has built a 1,000 million Yen ( $\$ 7$ million) technical centre at Tsukuba, north of Tokyo. And while foreign companies set up in Japan, Japan's industrial giants are rapidly building research institutes overseas (see Nature 338, 697; 27 April 1989), making national classifications a thing of the past.

David Swinbanks - A shift towards cooperative industrial research wins backing in a joint Japan-US report* issued last week by the US National Academy Press. The report has

\title{
Brain sections to be buried?
}

\section{Frankfurt}

CoIncident with its fortieth annual meeting, the Max Planck Society (MPS) last week announced plans to give a respectful burial to tissue samples from the brains of Nazi euthanasia victims that remain in its collections. According to Director Heinz Wässle of the Max Planck Institute for Brain Research (MPIBR) in Frankfurt, the brain tissue - fixed in thin sections on up to 10,000 glass slides - will be cremated and the ashes will be buried at an appropriate site, perhaps an existing Holocaust memorial.

The tissue samples were collected by neuropathologist Julius Hallervorden (1882-1965) from the euthanasia centre at Brandenburg-Görden. Hallervorden, a section leader at the Kaiser Wilhelm Institute for Brain Research in Berlin, the forerunner of MPIBR, received 697 brains from the centre between 1940 and 1944. Thirty of the tissue samples have been shown to derive from these brains; up to 400 samples have been linked circumstantially with the killing centres.

The Max Planck Society will cremate all slides and samples in its possession dating back to the years 1933 to 1945 . The permission from University of Frankfurt is required, but is expected to be granted.

A scandal erupted in Israel in January when a West German television report revealed the presence of tissue samples and skeletons of Nazi victims at the West German universities of Tübingen and Heidelberg (see Nature 337, 195; 1989).

The University of Tübingen appointed a commission to investigate the presence of such samples at the university and the possibility that they had been used for teaching. The commission is to meet soon and is expected to consider burial. The its origin in a meeting of 40 experts organized last summer by the US National Science Foundation and the Japan Society for the Promotion of Science.

Two broad areas where cooperative efforts might pay off were identified: definition of a computer-aided product realization system to help streamline the process of turning innovation into product, and basic research in intelligent manufacturing control systems to provide the scientific foundations for a totally automated, 'intelligent' factory. A third area of inquiry, on how universities and industry coordinate their research efforts, was scheduled for further discussion. The committees will meet again next year to present and compare plans for specific joint research projects. Alun Anderson * Manufacturing Research Exchange: Foundation of a Japan-US Cooperative Research Program. National Academy Press 1989.
University of Heidelberg is "still deciding" how best to dispose of four samples in its anatomical collections that may have been taken from Nazi victims, said spokesman Michael Schwarz. The samples may be buried at a memorial to Holocaust victims in a Heidelberg city cemetery. Neither university had heard of the MPS plans.

Wässle says that researchers have not used the Hallervorden samples in recent years, and that he and his co-director, Wolf Singer, did not know of the collection's existence when they arrived at the institute eight years ago. They learned of it only when historian Götz Aly tried to gain access to it in 1983 and "locked it away" in 1987 when Aly's book offered proof of its origins.

Cremating the collection respectfully seems to be the "only ethical solution", said Wässle, but he is also concerned that the reputation of science might suffer from further publicity. Meanwhile, the slides are locked in the basement room T0011 and are accessible only with a key stored in the director's desk.

The brains used by Hallervorden were removed from the cadavers of children who allegedly suffered from psychiatric disorders. Psychiatrist and historian Robert Jay Lifton estimates in his book The Nazi Doctors that 5,000 children were killed in the official Nazi euthanasia programme. Hallervorden continued to publish papers about his findings until his retirement in the early 1960 s.

Geneticist Benno Müller-Hill, who collaborated with Aly's investigation some years ago, said that it is important for the records of the collection to be retained even after the samples are destroyed. 